\title{
WATERWISE REFLECTIONS
}

\section{Marianne Cherrington}

\section{INTRODUCTION}

The joint UNESCO - Untouched World Foundation Waterwise is a field programme in partnership with Otago Polytechnic (OP), for young adult leaders, focussing on water/bio-diversity sustainable best practice. The weeklong December 2019 Waterwise Bannockburn programme considered use, quality, availability and economics of water as a resource in the Otago region. By interacting with key regional stakeholders, youth leaders gained a unique appreciation for the complexities of water issues and interconnectedness of human activity with the ecosystem. This article is a reflection from an Otago Polytechnic Auckland International Campus (OPAIC) staff member, as a facilitator. A view is given on lasting impressions and programme impacts for participants, and the process of behavioural change that began via the programme.

\section{WHAT HAVE I SIGNED UP FOR?}

At 9:09 a.m., 19 November, 2019, at my stand-up desk at OPAIC, an email popped up: Waterwise - leadership opportunity - Expressions of interest. Scanning, my eyes stopped at "UNESCO", followed by "looking for one (additional) OP staff member to join the team on this leadership journey." I clicked on the link and seven minutes later, I had sent my expression of interest and CV away for consideration. I went back to work, but before my lunch break had ended, I sent a message with supporting evidence in an email, explaining why I would be a good, albeit unusual choice. By the end of the week, I was offered a place, given some flight details and was asked to provide acceptance confirmation. I had already discussed the opportunity with my manager; my colleagues agreed to provide support. I had two weeks to prepare for a week away. It was the end of year, end of term. I had a conference paper to complete as well as my Graduate Diploma in Tertiary Education. What exactly had I signed up for?

In 1981, Peri Drysdale (MBE) established the Canterbury luxury merino fashionwear firm, Untouched World ${ }^{\mathrm{TM}}$, under the parent company Snowy Peak Limited. Troubled by environmental impacts, she questioned how might "every one person, every one company, make a difference?" (Founder, April, 2020). A journey began. Untouched World became the "first and only lifestyle fashion company in the world to be recognised by the United Nations, for sustainability." The firm is motivated by quality as well as holistic, sustainable product life cycle operations (Untouched World New Zealand, n.d.). Part of every purchase supports the Untouched World Foundation (UWF), to inspire young leaders' development relating to sustainable best practice. As a UNESCO Global Action Partner supporting the United Nations' Sustainable Development Goals (SDGs), UWF's programmes focus on quality education, clean water, biodiversity and partnerships (Untouched World Foundation, 2020). UWF Programme and Sustainability Director, Dr. Barry Law, has developed a student-centred framework which builds skills via experiential leadership, with collaborative problem-solving and mentorship from community specialists from wide-ranging milieus.

Research completed, I felt confident that while I was unsure of my role, I could make a valuable contribution. 


\section{GETTING UP TO SPEED}

I was still furiously working on unfinished tasks on the plane to Queenstown. I read Waterwise notes at the airport, including health and safety, leadership notes, experiential learning and global citizenship guidance, as well as kaupapa (Māori themes). The programme seemed well planned but not especially detailed. I wondered where I would be able to provide expertise. My fellow traveller arrived and we got acquainted. We had Northland commonalities and chatted on the 45-minute drive to our lodgings at Bannockburn School camp near Cromwell. We were greeted by lead facilitator, Caroline and sixteen students from eight Otago secondary schools. Nine tertiary Waterwise alumni were to lead, facilitated by a handful of educators. I thought we were a bit 'top heavy' with only sixteen students, but this was not to be my last misjudgement.

We began to get to know everyone by helping here and there, and attempting various icebreaker games. The kaupapa for the day was whanaungatanga, defined in the Māori dictionary as "relationship through shared experiences and working together which provides people with a sense of belonging. It develops as a result of kinship rights and obligations, which also serve to strengthen each member of the kin group" (Moorfield, 2005). I was soon to find out just how essential whanaungatanga was to the entire Waterwise programme.

A team roster was made for students to prepare tea, then tidy up. We took in our surroundings with a cuppa. Cromwell has an average $400 \mathrm{~mm}$ annual rainfall. Ironically, Otago had a deluge of heavy rain and thunderstorms; road closures delayed students' arrival. Cell-phone towers were down. We performed an icebreaker and reflected in our journals. The evening finished with groupwork on values, and issues of water quality availability as an essential to life. All in all, it was the most relaxing evening I had experienced in quite some time; I began to forget about Auckland's frantic pace and recalled living in Otago as an international student decades before.

\section{IN THE SPIRIT OF THINGS}

I woke early; I still had 'my day job' to attend to. One of our students jogged along the track as the sun rose. Soon the student breakfast team arrived; I packed up my work to lend a hand, but this resulted in too many cooks, so I sorted the pantry.

We had a briefing before the breakfast tidy up. We mind-mapped leadership in groups. I know leadership theory and pitfalls; this is where I could provide input! Yet it was all running quite well with the tertiary team roving as facilitators. I took a look. Some of the work was quite interesting and I pondered the different perspectives. I sat with the educators as proceedings concluded. As the students got prepared to head to the Cherry Block at the OP Bannockburn Campus, Caroline had a debrief with the tertiary team. I eavesdropped intently.

In the cherry orchard, we learned about its development and the Otago stone fruit industry. We tried a few ripe cherries. We learned how water was used with the auto-control systems and crop optimisation issues. From a management perspective, it was fascinating and some of the realities of having to irrigate were complex. The students had so many questions; it was a more engaging environment in which to learn than a typical classroom milieu. There were other students studying in classroom blocks here too, but they seemed more active and involved than usual. Everything seemed quite freestyle, which is ok for a leadership camp, I thought.

I wanted to stay longer, but we left for a lunch in the historical precinct in Cromwell. We could see and discover more about the contentious flooding of Lake Dunstan, in the early 1990s, for the Clyde Dam. The old town centre was underwater and a large part of the town was moved or rebuilt. As we strolled through the old town centre, we read about its partial relocation and walked further to see remnants of buildings partially engulfed. I recalled the controversy of the project when I was a student, and I thought environmentalists would never allow the Clyde Dam to be built today! I felt a nostalgic sadness and shrugged it off as 'the price of progress.' 
Next on the agenda was a visit to the Cromwell Historic Cemetery. When we arrived, we were prepared by Caroline as to the importance of this visit and the respect for this tapu (sacred) place. We were excused from entering if we felt uncomfortable. I followed one student who was very knowledgeable and could read Mandarin, who deciphered some of the tombstones of Chinese miners from the area. There were many headstones dated around the same time. I read the Scally family headstone; four children died in one month and then the mother and another child a year later. Apparently, an open water race was used by the early settlers. Those near the top of the hill were fine, but their waste and the typhoid that resulted took whole families. This surely was not the dream that propelled immigrants to leave everything behind to begin a new life. 'IN HOE SIGNO VINCES' arches the top of the stone and in Latin, it literally means 'in this, conquer.' Cruel comfort. I wasn't sure if typhoid killed Mrs Scally or heartbreak and despair but I struggled with tears and felt sick to my stomach. I had to get out; it was too overwhelming. I turned on a tap and sprinkled myself with fresh water.

\section{A SENSE OF COMMUNITY}

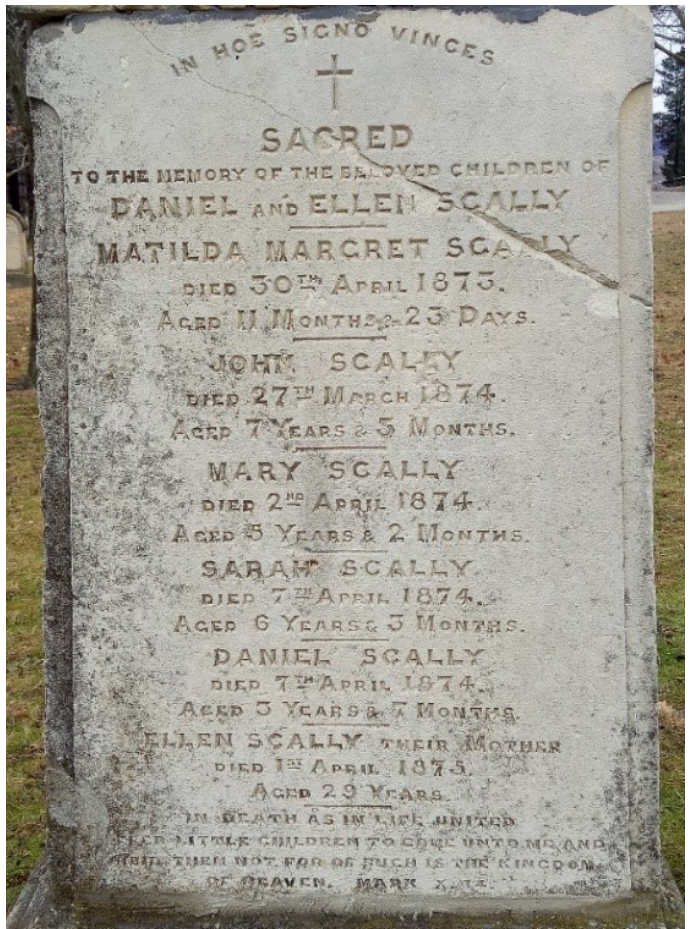

Figure I. Scally Headstone. Source: courtesy of the Historic Cemeteries Conservation Trust of New Zealand

We regrouped to share thoughts and feelings; the experience had left a deep impression. Even the segregation of the cemetery 'spoke volumes' and added to the sombre mood. I thought about how I had been teaching about United Nations' Sustainable Development Goals. It was all very clinical, theoretical and very detached from Auckland campus realities, but this was visceral learning. Inequity and despair resulting from a lack of clean water was chiselled in stone. It is no less of an issue in 2020. We took our time to ponder what we had seen as we drove a circuitous route past the OP campus, into Cromwell's town centre. I thought of my colleagues in Auckland and Dunedin and wondered how my international students were faring, so far from home.

The next task was more interactive and challenged us to get out of our comfort-zones. We began interviewing local residents and businesses about their perceptions regarding water in the Otago region. I thought two hours was a lot of time for a few questions, especially on a quiet Sunday afternoon. I tagged along as one group began a conversation about Waterwise and perceptions of water accessibility in the region. A lengthy exchange ensued with far-reaching comments made about dry conditions and water concerns in the area, despite the recent downpour and on-going drizzle. From household users, to business owners, to real estate agents concerned that development was proceeding without sufficient pause to consider resource management, this exercise provided a wealth of information and diverse perspectives on water issues. It also brought out the hidden communication skills of both outgoing as well as the more reserved students. Again, I was moved by the capabilities of the students; it was eye-opening.

The Cromwell community were so co-operative with our students, generous with time and forthcoming with views. Water is a precious yet contentious issue; people have opinions to share. I was humbled, grateful and taken aback. Perhaps people and organisations have a sincere desire for young people to learn and succeed. 
When we were back at the camp, we discussed the issues that were raised and shared perspectives from the afternoon. We also elaborated some of the transferable skills we were developing, related to the OP I am Capable Framework, supporting students with employable skills (I am Capable, n.d.).

The next leadership topic focused on how to direct influence and create impact; we discussed how to progress change with disconnected populations. This is suddenly very serious, I thought! Having a voice is one thing but implementing change is another. Then I recalled the Student Volunteer Army that arose from the Christchurch earthquakes (Student Volunteer Army, n.d.); I chided myself for being old and cynical. Then I recalled a former student who came out of his shell to suddenly ooze with charisma after reading the classic How to Win Friends and Influence People while activating its advice (Carnegie, 2005). Hmmm. I wondered how I could create more impact.

A film on the plight of the long fin eel ended the evening. It was obvious that we were connecting water usage with the Clyde dam, the flooding of Cromwell and the effects on nature. I was beginning to think of the more and many challenges that lay ahead. I couldn't focus; I had a million things running through my head simultaneously. My legs wanted to move but I felt stuck in the chair. I wanted to get up and run and shout, but instead, I sat on my hands.

\section{WIDER WATER WORRIES}

The next three days were full-on. Suddenly, the seemingly laissez faire setting was chocka block with industry visits, stakeholder perspectives and a tsunami of water issues. I soon realised the power of whanaungatanga and value of taking time to form as a team, because I witnessed students working together and debating issues from personal perspectives, gaining new insights, and using empathy while acknowledging others' views; they were action orientated. I had wondered how and why certain students had been selected and unusual events were occurring; emotion was held and released. Through these visits, respectfully, students were listening using their own field of experience. They also trusted each other and valued their differences. I was very much at the back of the group now and struggled as I searched for something that I could contribute. Appropriately, wairua (spirit) and mauri (life force) were our kaupapa themes and the buoyancy of the students lifted me up.

Monday began with a presentation at Cromwell Dry Garden, which promoted the use of common plants that were useful and more resistant to drought; common sense really. It was followed by hands-on restoration, protection and mulching of trees planted by the Mokihi Trust along the Kawerau River. Somehow the students made it a game and contest, so several weekends of work got done in a few hours. I should include more of these environmental working weekends in my calendar, I thought. We had an afternoon tour and water use discussion at the very hospitable organically-certified Carrick Vineyard in Bannockburn. They were very forth-coming answering questions about their sustainable management practices, especially regarding water and how they differed from some vineyards. They made us consider when water should be used to save crops.

The next day began early at the Crown Range Summit wetlands and with Otago Regional Council (ORC) representatives. We waded through the water and surveyed for aquatic life, discussing the water quality in the streams and ways to measure and assess impacts; new residential developments were just a few paces away. I thought about the streams I used to play in as a child with tadpoles and crawly things. These streams were scant in comparison.

We had a farm station visit at Hillend in the Cardrona Valley Catchment; along with ORC staff, a lively and frank discussion ensued. I was struck by the courteous exchanges. On one hand, farming practices with races and historical water rights were having to be re-examined. Farmers could not borrow to irrigate more effectively; Resource Management Act allocations were years away. Council staff were more likely to implement change if they worked with farmers via the ORC. Again, where your farm was, relative to the water source, was vital. Some of our students had farming backgrounds. Some families hunted for a living. Some students were vegetarian. You can hide in a city and close your eyes, but in small communities, environmental issues are everyday issues. 
Wednesday was electric; Clyde Dam was spilling spectacularly, as it had not done in twenty years! We had an informative visit through the control room, tunnels and inner workings of the dam. In a board room, we debated everything from historical controversies behind the building of the dam, to sustainable energy, to eel recovery plans. Students then broke into groups, debating Otago water usage issues from various perspectives. I chimed in playing devil's advocate at times and especially enjoyed the solutions that the students put forward for presentation after a fabulous lunch provided by Contact Energy. Finally, we explored Cromwell Museum and learned more about the history of Cromwell. Back at camp, we spoke about behavioural change topics with Dr. Barry Law.

It was an explosive three days. We were worn out! What really impressed me was that by the time we discussed behavioural change, the intention of Waterwise was starting to take shape. I belong to an era where we 'speak when spoken to' but I had seen students respectfully become part of the discussions at a very real, even emotional level. The objective of Waterwise is to make students agents of change. If older generations could make change happen, they would, but they are invested in their view. If we need change, now, then we need youth to instigate and lead. I remember asking my 92-year-old mother why they didn't do more about the environment, after all, Silent Spring was written in 1962 (Carson, 2009). It's older than I am. She said that they just didn't believe what the scientists were saying. Maybe that reality has not shifted much in decades.

Waterwise doesn't give students the answers; it surrounds them with the environment, experts and tools that they can 'try on' and develop. It doesn't tell them what they don't have or grade the answer. Waterwise lets students fit in where they are at and invites them to discover more and experience the value of their potential.

The next day, we had a gentler start, considering how to progress a more deliberate future. Then we went to study waste reduction at Wormworx, where they convert bio-waste and biodegradables into rich fertilizer and soil conditioner. Who knew chlorinated water significantly reduced the size of worms (and us)? Well, chlorine is a cheap way to a safe public water supply, I suppose. The bulk of the day was spent sifting through water quality issues and leadership. We discussed how we can be part of the 'next best action' in the short term, with a longterm vision of value. We pondered inter-generational contributions and conventions, and how collaborative effort can make things happen, a lot faster. I had gained a better understanding of my role; it was not to lecture.

The next day, as we packed up to leave, we reflected and reconnected. We had come together, lived together and learned together. Everyone had a unique input. Every person had a role to play. As I headed to the airport, my Northland friends discussed how the April Waitangi Waterwise program would be the same yet very different in the beautiful Bay of Islands. I knew Ngā Tupuranga o Te Taitokerau would be, just as I knew how dynamic and capable those Northland young leaders already were. I wanted to be there and to understand the issues. I wanted to be a part of the kōrero (narrative). I tried to soak in the views and beauty of Otago as it passed by and wondered at our impact and our footprint here, in New Zealand and from a global perspective.

\section{BACK TO THE REAL WORLD}

I had hours to wait for my flight. I had an assignment to complete and watched a Japanese grandmother feed her grandson as he played on an iPad. Everything seemed so much more significant now, but I knew not why. I managed to submit, then completed some emails. The boy had left his hat behind and I ran to give it to the mother; we smiled without words. Three generations on holiday in Queenstown; I flew back to Auckland.

I was back again soon to cycle the Otago Rail Trail. I viewed the water damage from the deluge of rain along the river's edge in Alexandra. Rain soaked me to the core when I passed NIWA at Lauder, so I sheltered in Hayes Engineering Works and Homestead for lunch. I felt as if Central Otago's 400 mm of rain only fell when I arrived! Or was this climate change? I stayed in Naseby, home to 120 residents and one of our tertiary students; it was full of holiday homes and of course was famous for the Naseby Indoor Ice Curling Rink. I cycled to Hyde and stayed in their pub, which no longer sells beer, and I took the Taieri Gorge Railway Train back to Dunedin to say 'kia ora' to Stu from Waterwise. We met at OP's Hub; Stu really knows how to walk the talk. 
It's just too easy to fall back into old habits and Auckland isn't Otago. It was the driest summer I had ever experienced. I had always saved rainwater for my vege garden, but there was none this summer. I washed dishes in a bucket to water my flowers. I saved water every way I could think of. Several trees died anyway and my figs didn't produce. By the beginning of April, Auckland's storage dams had about 65 per cent less rainfall than normal in the first three months of the year. But that was not the headline. The world was in lockdown due to COVID-I9. We were washing our hands while hoarding hand sanitiser and toilet paper. Zoonotic transfer was a different kind of assault on nature. Ironically, I was teaching about emissions reduction and Zero Carbon Act targets while the world had shut down and all industry had stopped. Targets achieved!

I wonder if we can go back to how we were. I wonder if I will still have a job. I wonder if I ever took as much time to walk everywhere in my community and really notice my surrounds. I smile and greet my neighbours. I am so proud of my international students stocking shelves on the night shift as they pull over on the deserted road home to have their online project team meeting at 8 a.m. I don't have any solutions, but I can do my bit.

And I am not idle; I have a lot to do. I'm grateful and fed up at the same time. I don't have to have all the right answers and people aren't really asking me for that anyway. What I do have to offer is guidance and support and some words that move things forward. That's what Waterwise taught me. We can have an impact and we do have a wealth of knowledge and experience; we all have a role to play in influencing positive change. We already have all the facts and solutions. All we have to do is to wake up and change (Thunberg, 2018).

\section{LEADERSHIP LESSONS}

How do I reconcile my job as a lecturer with the experiential learning I witnessed at Waterwise? I struggle with having a voice and holding my tongue. Arrogance and humility. I have to reinvent my role in the classroom and at home and in the community. I revamped my teaching papers over the New Year. I discovered many of my colleagues were engrossed in sustainability teaching and learning. Their support helped me spearhead several industry sustainability speakers on campus in the first term. It was easy. There is so much generosity towards young people that can be harnessed to build their spirit, their knowledge, and their confidence to lead.

I sip a Bannockburn wine with COVID-19 news on; my focus shifts. Jane Goodall stresses the value of youth leadership programmes in affecting change.

Every single one of us makes an impact every single day. We have a choice as to what sort of impact we are going to make and so yes, there are people in the high places in governments ... who listen, who get it and our Roots and Shoots programme with the young people, they are influencing their parents and grandparents, many of whom may be the heads of big corporations or ... governments

(Goodall, 2020).

Waterwise is not just a youth leadership programme at all.

Northland Waterwise was cancelled due to COVID-19. Water restrictions are in place in Auckland after a seven year wait for consents from the Waikato Regional Council. New Zealand is a 'team of five million' and growing. We want to water blast our decks and wash our cars; we can't wait to come out of lockdown. We haven't changed at all.

Lock-down kept us safe, so far. My students continue to study and some are essential workers, in supermarkets or as drivers; some will resume work in takeaways and warehouses. We make more time for whanaungatanga, wairua and mauri online. Sustainability is straightforward, but rangatiratanga (leadership) is our aspiration. 
Marianne Cherrington is a Senior Lecturer at Otago Polytechnic Auckland International Campus, studying Computer Science and Analytics. A lecturer in disruptive innovation, her research into machine-learning feature selection algorithms applies in many fields, producing interesting collaborations with international partners in many disciplines and sectors.

(1) https://orcid.org/0000-0002-1240-2010

\section{REFERENCES}

Carnegie, D. (2005). How to win friends and influence people. Houston: Cornerstone.

Carson, R. (2009). Silent spring. 1962.

Founder. (9 April, 2020). Snowy Peak. https://www.untouchedworld.com/about-us.htm

Goodall, J. (2020, April 25). BBC World News Interview with Jane Goodall [TV broadcast]. British Broadcasting Corporation. Retrieved from https://www.youtube.com/watch?v=alwWdokyUuE

Historic Cemeteries Conservation Trust of New Zealand (12 April, '20). Scally Family. Retrieved from www.cemeteries.org.nz/ stories/scallyfamily210309.pdf

lamCapable. (n.d.). i am capable. Retrieved from https://iamcapable.co.nz/

Moorfield, J. C. (2005). Te Aka: Māori-English, English-Māori dictionary and index. London: Longman.

Student Volunteer Army. (n.d.). Our story. Retrieved from https://sva.org.nz/our-story/

Thunberg, G. (2018, November). Transcript of "The disarming case to act right now on climate change." TED: Ideas worth spreading. Retrieved from www.ted.com/talks/greta_thunberg_the_disarming_case_to_act_right_now_on_climate_ change/transcript?language $=$ en

Untouched World Foundation. (2020, April). Modern Learning, Student Focused. Retrieved from www.untouchedworldfoundation. com/our-programmes

Untouched World New Zealand. (n.d.) About Untouched World. Retrieved from https://www.untouchedworld.com/about-us.htm 